\section{THE POSITIVE POTENTIAL OF THE ORGANISATION AND KNOWLEDGE PARTNERING}

\author{
Anna Adamik ${ }^{\mathrm{a}}$, Sylwia Flaszewska \\ Lodz University of Technology, \\ Department of Management, Lodz, Poland \\ a e-mail: anna.adamik@p.lodz.pl \\ b e-mail: sylwia.flaszewska@p.lodz.pl
}



0.12775/JPM.2015.014

\begin{abstract}
Purpose: Identify the key elements of the concept of Positive Potential of the Organisation (PPO) and provide the answer to the question whether the use of knowledge partnering can enhance the PPO.
\end{abstract}

Approach: This is a literature and research review paper.

Findings: The paper highlights the important role of knowledge partnering in the process of developing and strengthening the positive potential of modern organisations based on the example of high-tech enterprises operating in Poland. It can be noted that the analysed companies develop intraorganisational knowledge partnering significantly more often than inter-organisational knowledge partnering. At the same time, it has been shown that personalised knowledge is valued most by this kind of entities. Contacts with other partners from the business environment (customers, suppliers, etc.) are also highly valued. These factors exert a somewhat stronger influence on the development and the positive potential of high-tech medium and large enterprises and have a weaker impact on small enterprises. Although small high-tech enterprises need most the support flowing from the positive potential of knowledge partnering, in practice they still receive it to the smallest extent. In general, for the high-tech companies surveyed, knowledge partnering is to a large extent a real stimulus for market operations, as well as a catalyst for even the most difficult forms of cooperation, which means it can be considered as an important source of positive potential.

Implications: The study shows the need for integration of knowledge partnering practices and positive potential management. The study indicates that knowledge partnering creates growth of positive organisational potential.

Originality/value of the paper: The study suggests that well-developed processes of knowledge partnering stimulate competitive activities and the positive potential of not only large and mediumsized enterprises but also small ones.

Keywords: partnering, knowledge partnering, knowledge management, positive potential

Paper type: Research paper 
THE POSITIVE POTENTIAL OF THE ORGANISATION

Anna Adamik

Sylwia Flaszewska

Figure 1. The PPO structure

Source: The authors' own compilation on the basis of GlińskaNeweś, 2010.

\section{Introduction}

The concept of the Positive Potential of the Organisation (PPO) has lately arisen a great interest in the community representing management sciences, also in Poland. The authors dealing with this issue claim that the PPO is a new way of looking at organisations, focused on a search for such dynamics of phenomena that leads to the development of employees, supports their excellence and vitality, and cultivates outstanding achievements - both on the part of the organisation as a whole as well as people working there (Kalinowska-Andrian, 2006). Proponents of this trend also point out that providing organisations with the right conditions to cultivate positive emotions and characteristics (such as trust, cooperation, satisfaction, etc.) can contribute to better functioning of these entities and even achieving significantly higher financial results (Rozkwitalska, 2012). The question then arises how to ensure these conditions and what role knowledge partnering plays in this respect.

Therefore, the theoretical objective of the paper is to identify the key elements of the PPO concept and the empirical objective is to answer the question whether the use of knowledge partnering can enhance the PPO. Theoretical considerations are illustrated with the results of the research conducted by the authors of the paper in Poland in 2011-2015 among high-tech companies in the framework of their participation in various research projects [1]. The selection of enterprises for the research was dictated by their specific nature as they are entities focused on a continuous process of acquisition, development and application of knowledge which in their case becomes outdated very quickly (Flaszewska, 2014).

\section{The nature of the PPO and the role of knowledge partnering}

The PPO can be referred to a set of tangible and intangible resources, the structure of which is shown in Figure 1. M. Chodorek provided detailed characteristics of each component (2010).

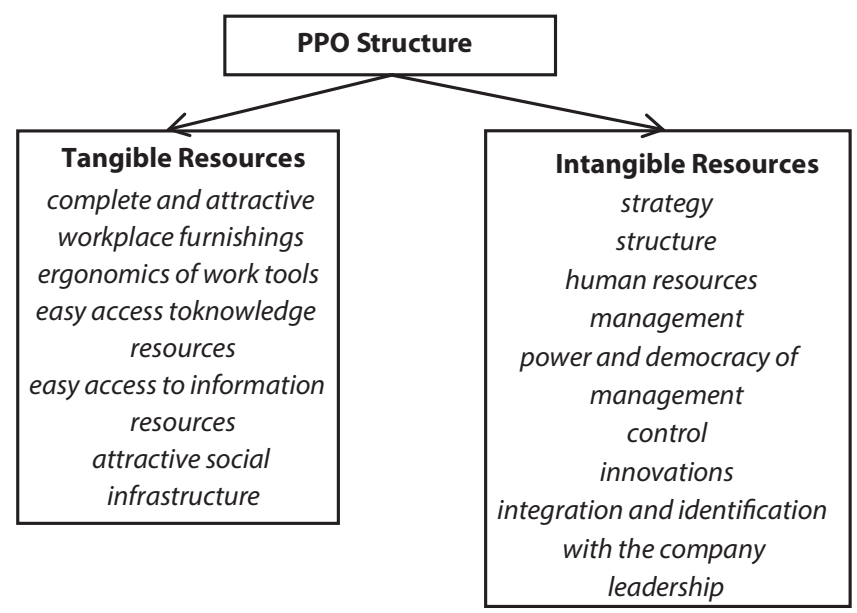


In the paper, the authors focus primarily on aspects related to knowledge as - in their opinion - stimulating its proper flow through knowledge partnering may enhance the PPO. This is not an isolated approach, as R. Haffer (2015) notes that the PPO is a collection of various theories and that studies undertaken within the framework of the PPO include, among others, the research trend focused on positive leadership (Cameron, 2008), practices in human resources management facilitating positive organisational phenomena (Hall and Las Heras, 2012) or the research trend focused on positive relations (Dutton and Ragins, 2007).

The last trend mentioned is closely linked with strategic partnering [2], that is an approach to management that due to its nature aims at the achievement of the stated objectives/projects by the partners through mutual support which results in increasing the resource efficiency of each of the partners. It requires the development of special relations between the partners and the practice of specific types of behaviour such as (Trusting the Team; Dyer, 1997; Grover et al., 1996; Cravens et al., 1996):

- relations aimed at achieving common objectives,

- agreed upon methods of solving problems,

- the division of responsibilities, costs and profits accepted by the parties,

- active search for continuous improvement,

- exchange relations in which all parties win through cooperation by achieving over time an advantage over entities remaining outside the relationship,

- long-term relations based on mutual trust and teamwork,

- cooperation between the owners, managers and employees, as well as,

- multi-lateral cooperation relationships related to the development of knowledge, technological competence and appropriate capabilities of the partners, i.e. knowledge partnering.

Knowledge partnering can be developed both within the organisation (intraorganisational partnering) and outside (inter-organisational partnering). Each enterprise must be able to co-create its own ecosystem in this area. Its quality, efficiency and competitiveness depend not only on the resources and skills of individual organisations initiating such ecosystems, but on the structure and quality of the created and exploited networks of relationships with different types of partners [3]. Nowadays, competition takes place not only between individual entities but between networks of organisations that skilfully manage their joint forces as well as resources, which they are not always owners of, obtained through this access (Iassiti and Levien, 2004). Choosing the right partners and establishing collaborative relationships based on appropriate terms provide an important source of not only competitiveness but also of securing a long-term development of the organisation (Adner and Kapoor, 2010). The role of different types of partnering 
THE POSITIVE POTENTIAL OF THE ORGANISATION

Anna Adamik

Sylwia Flaszewska in the case of enterprises of various sizes or operating in various industries is clearly illustrated by the criterion identifying the type of partners with which they establish partnering relationships. In the most common approaches, these partners are stakeholders of the organisation (Mitchel et al., 1997). Thus, in this context, strategic partners for the organisation are its key internal stakeholders, namely the owners and employees, as well as external ones, i.e. suppliers, customers, competitors, public or social organisations, etc.

In the first category, through initiating partnering relationships, individual (personalised) knowledge of particular employees [4] ceases to be solely owned by them. Thus, group knowledge is generated [5] and its essential feature is the possibility of synergies, i.e. combining knowledge of several people in order to achieve greater benefits. In the second category, partnering relationships are created between teams, leading to the development of organisational knowledge (a broadly defined potential of resources in the possession of the whole organisation, determining its long-term development). Then, inter-organisational partnering relationships are created [6], and through them inter-organisational knowledge is generated. In this case, there is an exchange of knowledge resources across multiple organisations and as a result the "shared" knowledge becomes a part of the enterprise's environment (Adamik and Flaszewska, 2013).

Knowledge partnering may fulfil various roles, for example, it is one of good practices used by high-tech enterprises aimed at improving knowledge management (Flaszewska, 2015). Thus used, it contributes to strengthening the positive potential of intangible assets held by these entities. This issue was dealt with indirectly in the first of the projects mentioned in the introduction.

Table 1 contains partial results of the survey conducted in the first quarter of 2015 in collaboration with external research company INSE Research.

The study used random sampling of the database purchased in the framework of the Bisnode system including 500 high-tech companies (according to the Polish Classification of Activity codes) and employing more than 50 people [7]. In most cases, the PAPI (Paper\&Pen Personal Interview) technique was used. This resulted in 100 completed questionnaires (of which 84 corresponded to completed interviews, in 16 cases, at the express request of the respondents, the questionnaire was completed without the participation of the interviewer and returned electronically). The target group of respondents consisted of managers of research and development departments or their employees. Regrettably, in many cases, an interview with those individuals was not possible, therefore authorised executives and employees from various other departments with expertise in the said field were allowed to respond instead. The study covered 55 mediumsized enterprises and 44 large enterprises. One respondent did not provide direct information on the number of employees, therefore, his questionnaire was omitted for the purpose of this publication. 


\begin{tabular}{lccc}
\hline $\begin{array}{l}\text { Directions for improvement of knowledge mana- } \\
\text { gement (good practices) }\end{array}$ & $\begin{array}{c}\text { Medium-sized } \\
\text { enterprises } \\
\text { (N=55) }\end{array}$ & $\begin{array}{c}\text { Large } \\
\text { enterprises } \\
\text { (N=44) }\end{array}$ & $\begin{array}{c}\text { Total } \\
{[\mathbf{8}]}\end{array}$ \\
\hline knowledge partnering (intra-organisational) & 42 & 34 & 76 \\
\hline $\begin{array}{l}\text { building loyalty } \\
\text { procedures that enable personalised knowledge } \\
\text { management }\end{array}$ & 87 & 10 & 52 \\
\hline $\begin{array}{l}\text { procedures for external cooperation in the field of } \\
\text { knowledge management }\end{array}$ & 16 & 18 & 34 \\
\hline $\begin{array}{l}\text { motivation system fostering creativity and innova- } \\
\text { tion }\end{array}$ & 40 & 29 & 69 \\
\hline $\begin{array}{l}\text { formation of units or positions directly related to } \\
\text { knowledge management }\end{array}$ & 17 & 15 & 32 \\
\hline $\begin{array}{l}\text { knowledge partnering (inter-organisational) } \\
\text { improving two-way communication between the } \\
\text { subordinate and the superior }\end{array}$ & 35 & 28 & 63 \\
\hline others, what kind? & 0 & 0 & 0 \\
\hline
\end{tabular}

THE POSITIVE POTENTIAL OF THE ORGANISATION

Anna Adamik Sylwia Flaszewska

Table 1.

Directions for improvement of knowledge management in the surveyed high-tech companies

Source: The authors' own compilation.

The results obtained indicate that the companies surveyed (76 entities out of 99) mostly improve knowledge management through intra-organisational partnering. This applies to medium-sized enterprises (42 out of 55) as well as large enterprises (34 out of 44). A much less popular direction of improvement of knowledge management is inter-organisational partnering, indicated by only 29 surveyed companies.

Due to the fact that knowledge partnering constituted only a small area of a larger study, the results of more detailed analyses carried out in this field are presented in the further part of the paper.

\section{Use of knowledge partnering in the process of strengthening the PPO}

In order to better illustrate the studied issue, more in-depth analyses of knowledge partnering among enterprises in the high-tech sector were carried out in the course of implementation of the second research project mentioned in the introduction. The study sample consisted of 402 enterprises and had a representative character. The studied population encompassed companies employing at least one worker and the companies that met the criterion of belonging to the high-tech industry, determined with the use of the domain method (according to the OECD) based on the Polish Classification of Activity (PKD 2007), which constituted the sampling unit. Quota sampling was used. The PAPI technique was used in the process of data collection. In its course, a structured and standardised questionnaire was filled by owners (53.7\% of the respondents) or members of the board of the surveyed companies (46.3\% of the respondents). Among the respondents, 
THE POSITIVE POTENTIAL OF THE ORGANISATION

Anna Adamik

Sylwia Flaszewska
Table 2.

The significance of selected knowledge resources for the development of the surveyed high-tech companies and the creation of their potential

Source: The authors' own compilation. companies producing computers, electronic and optical products comprised the largest group in the field of manufacturing (39.4\%) and computer science and telecommunications companies dominated in the high-tech sector (36.5\%) [9].

Among the studied resources of high-tech companies, widely understood knowledge proved to be particularly important for the development of their potential. Of the five types of knowledge (Table 2) that were evaluated by the respondents, personalised knowledge, i.e. skills and talents of employees, proved to be the most valued type of knowledge. $72.3 \%$ of the respondents attributed high or very high significance to it. Contacts of the respondents with other business environment partners (customers, suppliers, etc.) were also particularly highly ranked. $61.7 \%$ of the respondents believed them to be significant or very significant for the development of the potential of their companies. Due to the fact that these resources are one of the key elements of the positive potential of modern organisations, it can be said that the positive potential significantly, and often very significantly, influences the development and potential of high-tech companies.

\begin{tabular}{|c|c|c|c|c|c|c|}
\hline \multirow{2}{*}{$\begin{array}{l}\text { Type of } \\
\text { knowledge }\end{array}$} & \multirow{2}{*}{$\begin{array}{l}\text { Company } \\
\text { size }\end{array}$} & \multicolumn{5}{|c|}{$\begin{array}{l}\text { Significance of the given resource for the company's } \\
\text { development and creation of its potential }(\%)\end{array}$} \\
\hline & & 1 & 2 & 3 & 4 & 5 \\
\hline \multirow{5}{*}{$\begin{array}{l}\text { Technological } \\
\text { knowledge and } \\
\text { know-how }\end{array}$} & $S(n=253)$ & 14.6 & 7.9 & 33.2 & 28.5 & 15.8 \\
\hline & $M(n=106)$ & 4.7 & 4.7 & 33.1 & 34.9 & 24.5 \\
\hline & $L(n=43)$ & 2.3 & 11.6 & 25.6 & 32.6 & 27.9 \\
\hline & $\mathrm{N}=402$ & 10.7 & 7.4 & 31.8 & 30.6 & 19.4 \\
\hline & $\mathrm{N}=402$ & 18.1 & 31.8 & & 50.0 & \\
\hline \multirow{5}{*}{$\begin{array}{l}\text { Codified know- } \\
\text { ledge (databases, } \\
\text { collections of } \\
\text { information) }\end{array}$} & $S(n=253)$ & 5.9 & 13.4 & 32.8 & 33.6 & 14.2 \\
\hline & $M(n=106)$ & 1.9 & 5.7 & 34.0 & 40.6 & 17.9 \\
\hline & $L(n=43)$ & 2.3 & 7.0 & 25.6 & 34.9 & 30.2 \\
\hline & $\mathrm{N}=402$ & 4.5 & 10.7 & 32.3 & 35.6 & 16.9 \\
\hline & $\mathrm{N}=402$ & 15.2 & 32.3 & & 52.5 & \\
\hline \multirow{5}{*}{$\begin{array}{l}\text { Personalised } \\
\text { knowledge (skills } \\
\text { and talents of } \\
\text { employees) }\end{array}$} & $S(n=253)$ & 3.2 & 3.2 & 24.5 & 39.9 & 29.2 \\
\hline & $M(n=106)$ & 0 & 0.9 & 24.5 & 44.3 & 30.2 \\
\hline & $L(n=43)$ & 0 & 0 & 13.9 & 39.5 & 46.5 \\
\hline & $\mathrm{N}=402$ & 1.9 & 2.2 & 23.1 & 41.0 & 31.3 \\
\hline & $\mathrm{N}=402$ & 4.1 & 23.1 & & 72.3 & \\
\hline \multirow{5}{*}{$\begin{array}{l}\text { Contacts with the } \\
\text { high-tech compa- } \\
\text { nies and research } \\
\text { and development } \\
\text { centres }\end{array}$} & $S(n=253)$ & 9.4 & 11.9 & 33.6 & 27.7 & 17.4 \\
\hline & $M(n=106)$ & 2.8 & 7.5 & 28.3 & 41.5 & 19.8 \\
\hline & $L(n=43)$ & 0 & 4.6 & 37.2 & 20.9 & 37.2 \\
\hline & $\mathrm{N}=402$ & 6.7 & 10.0 & 32.6 & 30.6 & 20.1 \\
\hline & $\mathrm{N}=402$ & 16.7 & 32.6 & & 50.7 & \\
\hline
\end{tabular}




\begin{tabular}{|c|c|c|c|c|c|c|}
\hline \multirow{2}{*}{$\begin{array}{l}\text { Type of } \\
\text { knowledge }\end{array}$} & \multirow{2}{*}{$\begin{array}{l}\text { Company } \\
\text { size }\end{array}$} & \multicolumn{5}{|c|}{$\begin{array}{c}\text { Significance of the given resource for the company's } \\
\text { development and creation of its potential }(\%)\end{array}$} \\
\hline & & 1 & 2 & 3 & 4 & 5 \\
\hline \multirow{5}{*}{$\begin{array}{l}\text { Contacts with } \\
\text { other business } \\
\text { environment part- } \\
\text { ners (customers, } \\
\text { suppliers, etc.). }\end{array}$} & $S(n=253)$ & 1.2 & 5.1 & 34.8 & 37.1 & 21.7 \\
\hline & $M(n=106)$ & 0 & 1.9 & 31.1 & 46.3 & 20.7 \\
\hline & $L(n=43)$ & 0 & 0 & 34.9 & 25.6 & 39.5 \\
\hline & $\mathrm{N}=402$ & 0.8 & 3.7 & 33.8 & 38.3 & 23.4 \\
\hline & $\mathrm{N}=402$ & 4.5 & 33.8 & & 61.7 & \\
\hline
\end{tabular}

THE POSITIVE POTENTIAL OF THE ORGANISATION

Anna Adamik Sylwia Flaszewska

Where:1 - very insignificant resource; 2 - insignificant; 3 - moderately significant; 4 - significant, 5 - very significant resource;

$\mathrm{S}$ - small enterprises, $\mathrm{M}$ - medium-seized enterprises, $\mathrm{L}$ - large enterprises.

It should be also noted that the indicated elements of the positive potential have a slightly stronger influence on the development and potential of medium-sized and large high-tech companies than of small enterprises (it was confirmed by a study carried out in the framework of the third of the projects indicated in the introduction). In the high-tech sector, as in the whole economy, smaller businesses feel most acutely different types, specific to the size of the enterprise, of resource gaps, including the gaps in the positive potential of personalised knowledge and contacts/relationships with their business environment.

Regrettably, similar trends were also observed during the analyses of processes related to knowledge partnering, i.e. mechanisms supporting the creation of the positive potential of enterprises. Small high-tech enterprises, though they need most the support derived from the positive potential of knowledge partnering, in practice receive this kind of support to the smallest extent. This applies both to the intensity of support for competitive activities and initiating cooperation, especially with the most difficult of potential partners competitors (the last column of Table 3).

Nevertheless, generally for the surveyed high-tech companies, knowledge partnering is to a large extent a real stimulant of market activity (indicated by $43.5 \%$ of the respondents), as well as a catalyst for even the most difficult forms of cooperation (indicated by $33.6 \%$ of the respondents). It shapes not only the relational support and the support in terms of resources or but builds reputation, public acceptance and trust. Moreover, knowledge partnering opens the whole company and individual employees to processes of change and dynamics of the environment, as well as creates a culture of openness, along with atmosphere of cooperation and entrepreneurship, through which it extends the boundaries of their perception. Thus, it creates the 
THE POSITIVE POTENTIAL OF THE ORGANISATION

Anna Adamik

Sylwia Flaszewska

Table 3.

The role of

knowledge

partnering in

intensification of

market activity of

high-tech companies

Source: The authors' own compilation. positive potential in its own specific way. It seems that in today's economic conditions, especially for companies in this sector, its role simply cannot be overestimated.

\begin{tabular}{|c|c|c|c|c|c|c|}
\hline & \multirow[t]{2}{*}{$\begin{array}{l}\text { Company } \\
\text { size }\end{array}$} & \multicolumn{5}{|c|}{$\begin{array}{c}\text { Intensity of competitive } \\
\text { activities (\%) }\end{array}$} \\
\hline & & -2 & -1 & 0 & 1 & 2 \\
\hline \multirow{9}{*}{$\begin{array}{l}\text { Knowledge } \\
\text { partnering } \\
\text { (knowledge } \\
\text { management } \\
\text { system) }\end{array}$} & $S(n=253)$ & 3.1 & 4.3 & 30.0 & 21.7 & 40.7 \\
\hline & $M(n=106)$ & 1.9 & 5.7 & 23.6 & 17.0 & 51.9 \\
\hline & $L(n=43)$ & 9.3 & 4.6 & 30.2 & 16.3 & 39.5 \\
\hline & $\mathrm{N}=402$ & 3.5 & 4.7 & 28.4 & 19.9 & 43.5 \\
\hline & \multicolumn{6}{|c|}{ Intensity of initiating cooperation with competitors (\%) } \\
\hline & $S(n=253)$ & 1.6 & 5.1 & 37.9 & 36.0 & 19.4 \\
\hline & $M(n=106)$ & 1.9 & 6.6 & 36.8 & 31.1 & 23.6 \\
\hline & $L(n=43)$ & 2.3 & 4.6 & 25.6 & 25.6 & 41.9 \\
\hline & $\mathrm{N}=402$ & 1.7 & 5.5 & 36.3 & 33.6 & 22.9 \\
\hline
\end{tabular}

Where: -2 (barrier) hinders; -1 (inhibitor) inhibits; 0 no impact; 1 (catalyst) facilitates;

2 (stimulant) facilitates strongly

$\mathrm{S}$ - small enterprises, $\mathrm{M}$ - medium-seized enterprises, $\mathrm{L}$ - large enterprises.

In-depth analyses of knowledge partnering of the surveyed companies indicate that a very high and high level of ability to acquire and share knowledge in different areas of business environment, i.e. business knowledge partnering, among high-tech companies is predominantly responsible for such positive assessment of knowledge partnering (as indicated by $39.8 \%$ of the respondents (Table 4)).

The role of ability to cooperate with external entities in the area of developing new technologies - partnering in the field of high-tech knowledge - in these processes was evaluated slightly lower. Only $24.6 \%$ of the respondents indicated a high or a very high level of activity in terms of this type of actions to develop their potential and strengthen development processes. The latter type of knowledge partnering, by the virtue of its nature being more technically advanced, yet strategically more dangerous, is more difficult, both in execution and exploitation, thus it seems to enjoy less attention and popularity among practitioners. Examples of the achievements of individual companies indicate, however, that thus obtained specialised and often unique support is worth the effort. In quite a number of cases, the positive potential of partners' knowledge based on this support broke industry stereotypes, created breakthrough technologies, or set new standards. 


\begin{tabular}{|c|c|c|c|c|c|c|}
\hline \multirow{2}{*}{$\begin{array}{l}\text { Type of know- } \\
\text { ledge partne- } \\
\text { ring }\end{array}$} & \multirow[t]{2}{*}{$\begin{array}{l}\text { Company } \\
\text { size }\end{array}$} & \multicolumn{5}{|c|}{ Quality assessment (\%) } \\
\hline & & 1 & 2 & 3 & 4 & 5 \\
\hline \multirow{5}{*}{$\begin{array}{l}\text { Cooperation } \\
\text { with external } \\
\text { entities in } \\
\text { developing new } \\
\text { technologies } \\
\text { (high-tech } \\
\text { knowledge } \\
\text { partnering) }\end{array}$} & $S(n=253)$ & 33.6 & 19.8 & 27.3 & 14.2 & 5.1 \\
\hline & $M(n=106)$ & 15.1 & 12.3 & 39.6 & 31.1 & 1.9 \\
\hline & $L(n=43)$ & 18.6 & 7.0 & 39.5 & 23.2 & 11.6 \\
\hline & $\begin{array}{l}\text { Total } \\
\mathrm{N}=\mathbf{4 0 2}\end{array}$ & 27.1 & 16.4 & 31.6 & $\underline{19.6}$ & 5.0 \\
\hline & $\mathrm{N}=402$ & 43.5 & 31.6 & & 24.6 & \\
\hline \multirow{5}{*}{$\begin{array}{l}\text { Ability to acqu- } \\
\text { ire and share } \\
\text { knowledge in } \\
\text { other areas } \\
\text { (business know- } \\
\text { ledge } \\
\text { partnering ) }\end{array}$} & $S(n=253)$ & 0.4 & 3.5 & 6.7 & 7.5 & 1.6 \\
\hline & $M(n=106)$ & 5.7 & 10.4 & 31.1 & 43.4 & 9.4 \\
\hline & $L(n=43)$ & 9.3 & 9.3 & 23.2 & 30.2 & 27.9 \\
\hline & $\begin{array}{l}\text { Total } \\
\mathrm{N}=\mathbf{4 0 2}\end{array}$ & 16.9 & 13.4 & 29.8 & $\underline{29.1}$ & 10.7 \\
\hline & $\mathrm{N}=402$ & 30.3 & 29.8 & & 39.8 & \\
\hline
\end{tabular}

THE POSITIVE

POTENTIAL OF THE ORGANISATION

Anna Adamik Sylwia Flaszewska

Table 4. Quality of knowledge partnering in the surveyed high-tech companies

Source: The authors' own compilation.

Where:1- very low, 2- low; 3- moderate; 4- high, 5- very high;

$\mathrm{S}$ - small enterprises, $\mathrm{M}$ - medium-seized enterprises, $\mathrm{L}$ - large enterprises.

\section{Conclusions}

It seems that theoretical considerations as well as empirical research conducted among enterprises in the high-tech sector quite clearly indicate the importance of knowledge partnering in the process of developing and strengthening the positive potential of modern organisations. Although knowledge and processes related to its formation, development and accumulation may be slightly differently implemented in the case of companies not only from different industries but also of different sizes, they usually in one way or another lead to the strengthening of the potential of the partners involved. Also, to the strengthening of the positive potential. It should be noted, however, that having the potential (of any kind) does not automatically mean its exploitation. The PPO must therefore be appropriately stimulated and triggered, for example, through partnering which, due to its nature, enhances the effects of joint actions. Thus, it is a very desirable and favoured phenomenon.

\section{Notes}

[1] The project funded by the resources of the National Science Centre granted on the basis of the decision No. DEC-2013/09/N/HS4/03868, the research project NCN No. N N115 006040 financed by the research funds for the years 2011-2013 as well as the research project entitled Dojrzałość 
THE POSITIVE

POTENTIAL OF THE ORGANISATION

Anna Adamik

Sylwia Flaszewska partnerstwa międzyorganizacyjnego - analiza porównawcza zachowań małych, średnich oraz. dużych przedsiębiorstw (Maturity of inter-organisational partnering - a comparative analysis of the behaviour of small, medium-sized and large enterprises) in the framework of the "Dean's Grant" at the Faculty of Organisation and Management, Lodz University of Technology, implemented in the years 2014-2015.

[2] More information can be found in: Adamik, 2015.

[3] The specific nature and the role of strategic partnering of micro, small and medium-sized enterprises in relations with their basic stakeholders, i.e. consubstantial partnering (between the owners, the owners and the employees, between the employees), contract-based partnering (with suppliers, customers and competitors) and contextual partnering (with public and social organisations), in processes of creating their competitiveness is discussed in Adamik, 2015a.

[4] Individual knowledge is a unique entrepreneurial potential inherent in employees. Their skills and qualifications as well as commitment to the job constitute an essential factor in the development and success of the company. In order to survive in the globalised and computerised world, enterprises need to have at their disposal apart from, or perhaps above all, new technologies, also enterprising people who will provide their own unique, sustainable value. To attract and retain such people, the appropriate form of management, the right personnel policy and the proper development of organisational culture are necessary. It seems particularly important to introduce such a management system that will help identify people able to take risks, focused on achieving goals and obtaining results. Such a system has a chance to stimulate intra-entrepreneurship, i.e. the activity of persons acting on their own or in cooperation with other members of the organisation which will lead to taking advantage of opportunisties that arise through the implementation of projects which bring economic and non-economic effects to these persons, their organisations, as well as the environment. For more details see: Adamik, 2010.

[5] Group knowledge is associated with group entrepreneurship - today entrepreneurship is not just a set of characteristics that determine the individual's attitude towards reality, being entrepreneurial or active, enterprising, energetic, manifesting initiative, capable of taking the risk of acting, etc., but also a set of characteristics that determine the attitude of human teams: institutions, professional and local communities and whole societies. For more details, see: (Leibstein, 1968). [6] Relationships create a high-quality potential of each efficiently functioning organisation as they allow companies to decrease dependence on equity structures, reduce costs of negotiation (e.g.: by forming alliances) and improve economic performance. They can also significantly increase the effectiveness of learning from partners and provide the protection of their key skills and knowledge as they help develop many specialised routines aimed at the transfer of knowledge and information, which helps in not suspecting one's partner of any opportunistic behaviour, and thereby improves the transfer and assimilation of both explicit knowledge (various types of information) and tacit knowledge (in the form of know-how). Skillfully configured and exploited relational capital increases flexibility of operation as well as reduces transaction costs, increases innovativeness of partners and improves coordination of their actions. Thus, it contributes to the development of companies through the growth of their potential and credibility, as a result becoming an important strategic resource and a new way of looking at the value and development potential of the modern enterprise. For more details, see: Adamik, 2011.

[7] Limiting the population of high-tech companies to a group of medium-sized and large enterprises was a consequence of the focus surveys conducted earlier which covered representatives of micro, small, medium-sized and large enterprises. The analysis of the results obtained leads to the conclusion that in the case of micro and small enterprises, knowledge management is mainly based on intuitive actions of managers of these entities, therefore it was decided that in these cases the issue of knowledge management would not be explored.

[8] The respondents could choose more than one answer.

[9] For more information see: Zakrzewska-Bielawska, 2014. 


\section{References}

Adamik, A. (2010), "Managing relationships as a tool supporting enterprising actions in conditions of competitive economy", in: Lewicka, D. (Ed.), Organisation Management. Competitiveness, Social Responsibility, Human Capital, AGH University of Science and Technology Press, Kraków, pp. 13-31.

Adamik, A. (2011), "Kształtowanie relacji społecznych jako strategia budowy pozytywnego potencjału organizacji”, Prace Naukowe Uniwersytetu Ekonomicznego we Wrocławiu, No. 156, pp. 252-263.

Adamik, A. (2015), "Partnerstwo strategiczne a konkurencyjność przedsiębiorstw. Perspektywa MSP”, Zeszyty Naukowe Politechniki Łódzkiej, Vol. 1199, seria Rozprawy Naukowe Z. 484.

Adamik, A. (2015a), "Partnerstwo substanowiące, kontraktowe i kontekstowe - zachowania kluczowe dla nowoczesnych organizacji”, in: Bednarska-Wnuk, I., Michalak, J. M., Świątek-Barylska, I. (Eds.), Zachowania organizacyjne. Organizacja jako przestrzeń kształtowania zachowań pracowników, Wydawnictwo Uniwersytetu Łódzkiego, Łódź, pp. 9-25.

Adamik, A., Flaszewska, S. (2013), "Partnerstwo wiedzy jako determinanta działań przedsiębiorczych”, in: Flaszewska, S., Lachiewicz, S., Nowicki, M. (Eds.), Społeczne $i$ organizacyjne czynniki rozwoju przedsiębiorczości, Monografie Politechniki Łódzkiej, Łódź, pp. 39-40.

Adner, R., Kapoor, R. (2010), "Value creation in innovation ecosystems: How the structure of technological interdependence affects firm performance in new technology generations", Strategic Management Journal, Vol. 31 No. 3, pp. 306-333. DOI: http://dx.doi.org/10.1002/smj.821

Cameron, K. S. (2008), Positive Leadership. Strategies for Extraordinary Performance, Berrett-Kohler, San Francisco.

Chodorek, M. (2010), "Stan Pozytywnego Potencjału Organizacji w polskich przedsiębiorstwach - wyniki badań", in: Stankiewicz, J. (Ed.), Pozytywny Potencjał Organizacji. Wstęp do użytecznej teorii zarządzania, TNOiK Dom Organizatora, Toruń, pp. 53-56.

Cravens, D. V., Piercy, N. F., Shipp, S. H. (1996), "New Organizational Forms for Competing in Highly Dynamic Environments: The Network Paradigm", British Journal of Management, Vol. 7 No. 3, pp. 203-218. DOI: http://dx.doi. org/10.1111/j.1467-8551.1996.tb00115.x

Dutton, J. E., Ragins, B. R. (Eds.) (2007), Exploring Positive Relationships at Work: Building a Theoretical and Research Foundation, Lawrence Erlbaum, New York.

Dyer, J. (1997), "Effective Interfirm Cooperation: How firms Minimize Transaction Costs And Maximize Transaction Value", Strategic Management Journal, Vol. 18 No. 7, pp. 535-556.

Flaszewska, S. (2014), “Zarządzanie wiedzą z perspektywy praktyków z przedsiębiorstw high-tech", Marketing $i$ Rynek, No. 5, pp. 952-957.

Flaszewska, S. (2015), "Struktura organizacyjna jako instrument zarządzania wiedzą w przedsiębiorstwach wysokich technologii”, Ph.D. dissertation, Faculty of Organisation and Management, Lodz University of Technology, Łódź, pp. 149-150.

Glińska-Neweś, A. (2010), "Pozytywny Potencjał Organizacji jako prorozwojowa ar-
THE POSITIVE

POTENTIAL OF THE ORGANISATION

Anna Adamik Sylwia Flaszewska 
THE POSITIVE POTENTIAL OF THE ORGANISATION

Anna Adamik Sylwia Flaszewska chitektura zasobów przedsiębiorstwa", in: Stankiewicz J. (Ed.), Pozytywny Potencjał Organizacji. Wstęp do użytecznej teorii zarzązania, TNOiK Dom Organizatora, Toruń, pp. 48-50.

Grover, V., Cheon, M. J., Teng, J. T. C. (1996), “The Effect of Service Quality and Partnership on the Outsourcing of Information Systems Functions", Journal of Management Information System, Vol. 12 No. 4, pp. 89-116. DOI: http://dx.doi.org/10.1080/074 21222.1996.11518102

Haffer, R. (2015), "Determinanty i następstwa satysfakcji pracowników w świetle teorii pozytywnego zarządzania", Prace Naukowe Uniwersytetu Ekonomicznego we Wrocławiu, No. 376, pp. 152-153.

Hall, D. T., Las Heras, M. (2012), "Personal Growth Through Career Work: a Positive Approach to Careers", in: Cameron K. S., Spreitzer, G. M. (Eds.), The Oxford Handbook of Positive Organizational Scholarship, Oxford University Press, New York.

Iansiti, M., Levien, R. (2004), The Keystone Advantage: What the New Dynamics of Business Ecosystems Mean for Strategy, Innovation, and Sustainability, Harvard Business School Press, Boston.

Kalinowska-Andrian, K. (2006), "Positive Organizational Scholarship - nowy trend w nauce zarządzania”, E-mentor, No. 3/13, available at: http://www.e-mentor.edu.pl/ artykul/index/numer/13/id/235 (accessed 20 September 2015).

Leibstein, H. (1968), "Entrepreneurship and Development”, American Economic Review, Vol. 58 No. 2, pp. 48-49.

Mitchel, R. K., Agle, B. R., Wood, D. J (1997), “Toward A Theory of Stakeholder. Identification and Salince: Defining the Principle of Who and What Really Counts", Academy of Management Review, Vol. 22 No. 4, pp. 853-858.

Rozkwitalska, M. (2012), "Interakcje międzykulturowe w ujęciu Pozytywnego Potencjału Organizacji”, Organizacja i Kierowanie, Vol. 4 No. 153, pp. 16-18.

Trusting the Team, Bennett, Jayes, The Reading, Construction Forum, available at: http:// www.thomastelford.com.; www.businessdictionary.com/definition/partnering.html (accessed 20 September 2015).

Zakrzewska-Bielawska, A. (2014), "Metodyka badań empirycznych", in: ZakrzewskaBielawska, A. (Ed.), Koopetycja w rozwoju przedsiębiorstw high-tech. Determinanty i dynamika, Wydawnictwo Placet, Warszawa, pp. 93-131. 